This is an electronic reprint of the original article. This reprint may differ from the original in pagination and typographic detail.

Author(s): Sahradyan, Sonya

Title: Learning and maintaining languages in the workplace : migrant NGO practitioners in Finland

Year: $\quad 2017$

Version:

Please cite the original version:

Sahradyan, S. (2017). Learning and maintaining languages in the workplace : migrant NGO practitioners in Finland. In J.-C. Beacco, H.-J. Krumm, D. Little, \& P. Thalgott (Eds.), The Linguistic Integration of Adult Migrants / L'intégration linguistique des migrants adultes : Some lessons from research / Les enseignements de la recherche (pp. 329-334). Mouton de Gruyter. https://doi.org/10.1515/9783110477498-045

All material supplied via JYX is protected by copyright and other intellectual property rights, and duplication or sale of all or part of any of the repository collections is not permitted, except that material may be duplicated by you for your research use or educational purposes in electronic or print form. You must obtain permission for any other use. Electronic or print copies may not be offered, whether for sale or otherwise to anyone who is not an authorised user. 


\title{
Learning and maintaining languages in the workplace: migrant NGO practitioners in Finland
}

\begin{abstract}
This article reports on a linguistic ethnographic study exploring migrant NGO practitioners' language learning and maintenance at work. The findings suggest that the migrants learnt not only the language of the receiving society, in this case Finnish, but also English as an additional language through work. The narratives also show that the workplace supported migrants in maintaining both their home language and additional languages. Overall, the study highlights the importance of language learning and maintenance, which promote the linguistic integration and social inclusion of migrant NGO practitioners in the workplace.
\end{abstract}

Résumé : L'article rend compte d'une étude ethnographique sur l'apprentissage et la consolidation de la langue des praticiens qui travaillent dans des ONG de migrants. Elle conclut que les migrants ont appris non seulement la langue du pays d'accueil - dans ce cas, le finnois - mais aussi l'anglais comme langue supplémentaire, par le biais du travail. Les auteurs montrent également que le travail aide les migrants à consolider la fois leur langue maternelle et des langues étrangères. De façon générale, l'étude souligne l'importance de l'apprentissage et de la consolidation de la langue pour favoriser l'intégration linguistique et sociale des praticiens migrants dans les ONG sur le lieu de travail.

\section{Introduction}

In Finland, language has increasingly become a policy priority, and linguistic research has recently focused on various migrant groups working in different sectors. The Finnish integration policy supports migrants in learning national languages, Finnish and Swedish, and in maintaining their mother tongue, regardless of their legal status (Act on the Promotion of Immigrant Integration 1386/2010). In addition, scientific studies have revealed that migrants have an opportunity to develop their Finnish language skills in the workplace (e.g.

Sonya Sahradyan, Centre for Applied Language Studies, University of Jyväskylä, Finland, E-mail: sonya.s.sahradyan@jyu.fi

DOI 10.1515/9783110477498-045, (cc)BY-NC-ND @ 2017 Sonya Sahradyan, published by De Gruyter. This work is licensed under the Creative Commons Attribution-NonCommercial-NoDerivs 3.0 License. 
Suni 2010; Tarnanen, Rynkänen, and Pöyhönen 2015). Several studies have also indicated that the workplace enables migrants to maintain their home language within the Finnish context (e.g. Rynkänen et al. 2014). Even though language learning and maintenance have been studied among migrants working in the Finnish public and private sectors, relatively little research has been conducted on migrants working in the third sector, namely a non-governmental organization (NGO), or their language learning and maintenance at work.

This article, therefore, attempts to fill the above-mentioned gap by providing answers to the following question: "How do migrant NGO practitioners learn and maintain languages in the workplace?” The linguistic ethnographic study presented in this paper is conducted in a superdiverse NGO based in Finland. The key participants in the study are migrant NGO practitioners, that is, employees, apprentices, trainees, interns, and volunteers.

\section{A sociocultural approach}

In my research, I draw upon the sociocultural perspective on language learning. From this perspective, language is situated in a context co-created in social interaction and is learned from others within this interaction (Vygotsky 1978). In addition, I build on workplace learning research, which emphasises that learning is a product of involvement in social practices, for example, happening in workplaces (Billett 2002). The study conducted by Billett also highlights that learning is formed by "workplace participatory practices" and can be "co-participative" (2002: 1). Moreover, Malloch and her colleagues shed light on the fact that learning and performance are "embodied phenomena" (Malloch et al. 2011: 24). By combining these two strands of research, I consider language learning to be situated in different settings and to take place through social interaction and participation at work (see Tarnanen, Rynkänen, and Pöyhönen 2015), which concerns language maintenance in the workplace as well (see Rynkänen, Sahradyan, and Tarnanen 2014).

\section{Informants, data, and methods}

The study focuses on migrant NGO practitioners $(n=22)$ who were first-generation adult migrants. They were working as part- or full-time employees, apprentices, trainees, interns, or volunteers in the superdiverse organisation located in Jyväskylä, Finland. The informants had various cultural and socio-economic backgrounds, and they all spoke more than two languages. At the time of the 
interviews, the informants were between 23 and 61 years old, and they had resided in Finland for between three and 29 years. The level of education the informants had received before moving to Finland ranged from primary to university, whereas their level of education obtained in Finland ranged from integration training to university education.

Within the framework of linguistic ethnography, I collected different types of data through multi-site ethnographic fieldwork for a one-year period in the NGO. In addition, I conducted interviews with the informants. In this paper, only the interview and observational data are reported. Narrative analysis is applied to the multilingual data accumulated in four different languages: Finnish, English, Russian, and Armenian.

\section{Language learning and maintenance in the workplace}

All the migrants participating in this study were multilingual, and they had different proficiency levels in different languages. In the case of Finnish, the informants' proficiency levels ranged from basic to advanced, and they learnt Finnish both within and outside formal educational settings. Based on the data analysis, the NGO as a workplace provided the informants with opportunities to develop their Finnish language skills. In their narratives, the informants repeatedly talked about Finnish language learning at work, which is illustrated in the following quote: "I was learning Finnish every single day from colleagues and visitors, from job-related activities, tasks and paperwork" (Hudi, trainee). Like Hudi, most of the other informants also recognised the importance of the workplace for learning Finnish. However, whether they could improve their written or oral skills or both in Finnish depended on their type of employment.

In general, the informants learnt Finnish by participating in various activities and events organised in the workplace. One of them is ABC-Basic Finnish language learning, provided to migrant learners, especially to newly arrived, elderly, and illiterate migrants as well as to stay-at-home mothers. The informants were involved in this activity as mediators and had an opportunity to enhance their Finnish skills while helping with the interpretation or elaboration of what is said by migrant learners and Finnish volunteers acting as teachers. The homework club is another important activity in which the informants' Finnish language learning took place during the completion of young migrants' homework for different school subjects. However, during cultural evenings, the informants developed not only Finnish but also English skills by presenting 
and discussing the history, culture, language, and religion of their home countries. Similarly, ethno-cafés supported the informants in learning both Finnish and English while cooking traditional food together with Finns and migrants from different parts of the world.

Almost all the informants also found staff meetings very useful for developing their language skills in Finnish, and some informants mentioned that the meetings could help them to overcome challenges related to understanding and communicating in spoken Finnish. One of the informants said: "We usually had staff meetings every week in order to plan and organise activities with colleagues ... It was good to be there, 'cause I had difficulties in suomen puhekieli [spoken Finnish], but in meetings I could learn puhekieli [spoken language] and even could use it outside of work" (Sara, intern). Such a narrative is common in the stories of migrants and, in particular, interns' and trainees' stories. Additionally, another informant gave the following description: "Meetings that we had with authorities were only in Finnish, but meetings with partner projects or organisations were sometimes in Finnish and sometimes in English or both in Finnish and English ... In those meetings I practised Finnish as well as English" (Fabian, employee). As seen from the last two excerpts, the meetings with insiders supported the informants in improving mainly Finnish skills, whereas the meetings with outsiders enabled them to enhance both Finnish and English skills.

In addition to language learning, the workplace considerably influenced the maintenance of informants' languages, especially their home language. For example, it is illustrated in Bela's narrative: “At work I use also my mother tongue, Russian ... At the beginning of my work, it was a bit difficult to remember pycские слова ['Russian words'] as after moving to Finland I used English and then Finnish дома или с друзьями ['at home or with friends'] ... I think I was gradually losing my mother tongue before getting this job” (Bela, employee). Apart from the informants' stories, my observational field notes reveal that the workplace also supported informants in maintaining their additional languages. One of the participant's observational field notes are presented here:

One afternoon we were discussing different countries' holidays in our Russian discussion group. The group leader, Лаypa ['Laura'], was Russian and we, the participants, were both Finns and migrants. Laura was helping us to use a correct flpulyufüluf jun fiuphnu ['grammatical conjugation' (Armenian)] and was giving a short explanation in Russian and/or Finnish. During the conversation, Klara who had a migrant background asked Laura to explain in English as well, if possible, because, she told, that she had only basic level in Finnish. Laura smiled and replied "Well, it's better for me to say also in English, I can refresh my English and can keep it alive” (Laura, volunteer). 


\section{Conclusions}

In this article, I have addressed one main question related to the language learning and maintenance of migrant NGO practitioners in the workplace. The analysis reported above suggests that the workplace supported the informants in developing additional languages, such as Finnish, the language of the host society, and English. Also, it was found that the informants had an opportunity to preserve their home and additional languages with the help of their work. Furthermore, the narratives show that language learning (see also Tarnanen, Rynkänen, and Pöyhönen 2015) as well as language maintenance (see also Rynkänen, Sahradyan, and Tarnanen 2014) are situated, and they take place through social interaction and participation in different workplace settings. The study thus illustrates that language learning and maintenance foster the informants' linguistic integration and social inclusion at work. In the light of these findings, the paper gives new insights into migrants' workplace language learning and their language maintenance through work.

\section{Acknowledgements}

The study is part of bigger research projects "Transforming Professional Integration” (principal investigator, Professor Sari Pöyhönen) (2011-2014 / http://in tegration.jyu.fi) and "Language and Superdiversity: (Dis)identification in Social Media” (principal investigator Professor Sirpa Leppänen) (2012-2016; https:// www.jyu.fi/hum/laitokset/kielet/tutkimus/hankkeet/lgsd), funded by the Academy of Finland and implemented at the University of Jyväskylä.

The paper draws on the empirical data collected by the author for her doctoral dissertation, which is funded by the Kone Foundation and the Centre for Applied Language Studies, University of Jyväskylä.

\section{References}

Billett, Stephen. 2002. Workplace pedagogic practices: Participation and learning. Australian Vocational Education Review 9(1). 28-38.

Integration Act. 2010. Act on the Promotion of Immigrant Integration 1386/2010. Ministry of Interior, Finland. Unofficial translation.

Malloch, Margaret, Len Cairns, Karen Evans \& Bridget N. O’Connor (eds.). 2011. The SAGE handbook of workplace learning. London: Sage. 
Rynkänen, Tatjana, Sonya Sahradyan, Mirja Tarnanen, David Hoffman \& Sari Pöyhönen. 2014. The coffee room as threshold - social dynamics in workplaces in Finland. Paper presented at the International Conference on Sociolinguistics Symposium 20: Language, Time, Space, University of Jyväskylä, 15-18 June 2014.

Suni, Minna. 2010. Työssä opittua: työntekijän näkökulma ammatilliseen kieli- ja viestintätaitoonsa. ['Learned at work: An employee's perspective on their professional language and communicative skills']. In Mikel Garant \& Mirja Kinnunen (eds.), AFinLA-e: Soveltavan kielitieteen tutkimuksia 2. 45-58. Jyväskylä: Finnish Association for Applied Linguistics.

Tarnanen, Mirja, Tatjana Rynkänen \& Sari Pöyhönen. 2015. Kielen käyttö ja oppiminen aikuisten maahanmuuttajien integroitumisen ja identiteettien rakennusaineena ['Language use and learning in integration and construction of identities among adult migrants']. In Teppo Jakonen, Juha Jalkanen, Terhi Paakkinen \& Minna Suni (eds.), AFinLA vuosikirja 73: Kielenoppimisen virtauksia - Flows of language learning. 56-72. Jyväskylä: Finnish Association for Applied Linguistics.

Vygotsky, Lev. 1978. Mind in society: The development of higher psychological processes. Cambridge, MA: Harvard University Press. 